\title{
Empirical Investigation on the Impact of Public Expenditures on Inclusive Economic Growth in Morocco: Application of the Autoregressive Distributed Lag Approach
}

\author{
Imad KHANCHAOUI ${ }^{1}$, Sara El Aboudi ${ }^{3}$ \\ Organizational Management Sciences Lab National School \\ of Business and Management (ENCG) \\ Ibn Tofail University, Kénitra, Morocco
}

\author{
Abdeslam EL MOUDDEN ${ }^{2}$ \\ Organizational Management Sciences Lab National School \\ of Business and Management (ENCG) \\ Ibn Tofail University, Kénitra, Morocco
}

\begin{abstract}
Today more than ever, the international institutions (the IMF, the World Bank, the OECD and the UN) as well as the public authorities are interested in questions related to the development issue in general, and more particularly to inclusive growth. The reason is that in most developing countries, such as Morocco, the increase in economic growth does not necessarily and automatically have an effect on poverty and social disparities reduction. In this context, the study aims to analyse the impact of public expenditures, in particular the human capital development expenditure (education and health) and the public investment, on inclusive economic growth in Morocco through the use of the autoregressive distributed lag (ARDL) model on annual macroeconomic data from 1980 to 2018 and the bounds cointegration test of Pesaran. The results of the estimates show that, in the long term, public investment expenditures positively contribute to economic growth. Furthermore, they revealed that strong government action on human capital development expenditures is the most powerful instrument for enhancing inclusive economic growth in Morocco.
\end{abstract}

Keywords-Inclusive economic growth; public expenditures; human capital development expenditures; public investment expenditures; cointegration; ARDL model

\section{INTRODUCTION}

Public expenditures in Morocco, like other developing countries, have long been considered as an important lever for economic and social development. Indeed, the argument adopted by the public authorities is that these expenditures should positively influence the elements of domestic demand, namely consumption and investment, and, therefore, contribute to the revival of economic activity.

In this context, Morocco has multiplied its efforts in terms of public expenditures during the last decade, which has enabled progress to be made in the implementation of strategic sectoral plans and the launching of major infrastructure projects. However, despite these considerable efforts, the impact on inclusive economic growth and on reducing poverty as well as social and territorial disparities is not clearly tangible.

In fact, with the pace acceleration of public expenditures, Morocco is facing several budgetary constraints, particularly those related to the mobilization of public revenue, the size of incompressible expenditures, and the accumulation of budget deficits. These deficits and their structural nature can generate risks of medium and long term unsustainability of public debt, and a crowding out effect on the private sector.

In the current context characterized by: (i) globalization where each State aspires to economic growth and development, and (ii) recent developments in the global economy, in particular the public debt crisis in several countries, which have shown how important it was for an economy to promote the macroeconomic framework balance, the question of public expenditures efficiency is one of the major concerns of political decision-makers and economists in Morocco.

Hence, an adequate public expenditure policy must take in to account the budgetary constraints in the medium-term, while effectively meeting the objectives of inclusive development of the population in general. To achieve this, wealth would necessarily have to be increased, which implies a positive and sustainable action on economic growth.

The article is structured as follows. In Section II, we present a brief review of the literature and empirical review on the links existing between public expenditures and inclusive economic growth. In Section III, the study clarifies the data and the methodology used. Section IV presents the results of the estimation.

\section{LITERATURE, EMPIRICAL REVIEW AND INCLUSIVE GROWTH IN MOROCCO}

\section{A. Theoretical Literature}

Fiscal policy, combined with monetary policy, has long been one of the main instruments used by governments to intervene and influence economic activity. Thus, depending on economic conditions, public expenditures and taxes are used to influence the economy in the direction of expansion or contraction. However, the views and theories on the effectiveness of this fiscal instrument have often been contradictory.

Thus, John Maynard Keynes gave a theoretical basis for the use of fiscal policy, showing that public expenditures and taxes 
are an effective tool for regulating economic cycles. According to this theory, insufficient aggregate demand is the main cause of economic recessions. Hence, the need to increase public expenditures or the private expenditures of citizens following tax cuts increases their power to purchase and therefore consumption, to stimulate short-term economic growth [1]. In fact, for Keynesians, there is a relationship between the level of expenditure and national income (and therefore employment), since the increase in expenditure stimulates household consumption and encourages producers to increase their production to cope with additional demand, and, thus, create jobs.

However, the use of public expenditures, recommended by Keynes, as one of the main instruments for improving economic growth and fighting unemployment, which prevailed for almost forty years, was no longer unanimous in the early seventies. Indeed, several counter arguments and theories antiKeynesians were developed following the oil crisis of 1973, in which the global economy experienced an unprecedented recession characterized by the coexistence of high levels of unemployment and inflation.

Therefore, according to the Monetarists, public expenditure can decrease unemployment over time, due particularly to the phenomenon of the "money illusion" of the economic agents. However, they emphasize the perverse effects of these expenditures, especially the crowding-out effect, which exacerbates rather than lessens economic disruption.

Indeed, in a context of state financial resources scarcity, the increase in public expenditures financed by public debt would translate into a situation of lower funding for the private sector. Likewise, the accumulation of budget deficits would be manifested by increases in interest rates and, in the medium term, in prices and wages, which would cause a rise of the unemployment rate.

However, the economists of the Endogenous Growth Theory are halfway between the two schools of economic thought (the Keynesians and the Monetarists) such as Romer, Lucas, Sala-i-Martin and Barro. Consequently, for these economists public expenditure is not considered as a whole, but they make a distinction between the different types of expenditure [2].

According to the theory of endogenous growth, public expenditure on investment in human capital will stimulate economic growth, since innovation, research and development $(\mathrm{R} \& \mathrm{D})$ and their diffusion in the production process in a country is only the result of well-trained human capital. Similarly, this theory considers that public investment expenditures (infrastructure, health, education) could have positive externalities on growth in the long-term.

\section{B. The Empirical Review}

Faced with theoretical uncertainty about the relationship between public expenditures and economic growth, several empirical studies have attempted to approach the correlation relationship between these two aggregates, and to try to answer the fundamental question: Can public expenditures have positive effects on economic growth or not?
In this context, this section briefly presents an empirical literature review dealing with the effects of public expenditures on economic growth using the Vector Autoregressive (VAR) Models approach.

The results of a VECM model (Vector Error Correction Model), according to the Johansen approach, show that government revenues and gross fixed capital formation have a significant positive long-term impact on economic growth in South Africa. However, government expenditures and public debt are negatively correlated with long-term economic growth [3].

According to Kaur (2018) [4], the results of a VECM model indicate the absence of short-term causality between the government spending and economic growth in India. In the long term, revenue expenditure per capita is the main cause of the country's economic growth.

The estimation of a structural VAR model (VARs) of the Moroccan economy according to the recursive approach and Blanchard and Perotti's approach (2002) [18], reveal the following main results:

1) An expenditure shock has a positive effect on production (GDP) between the sixth and twelfth quarter;

2) The interest rate and inflation react positively to the expenditure shock, but this effect is not statistically significant;

3) A tax revenue shock affects negatively the production (GDP), inflation, while the interest rate reacts positively [5].

In Algeria, public health expenditure has a positive and significant impact on real GDP; however it is not significant in the short term. In addition, short and long term estimates also show that gross fixed capital formation and export hydrocarbon revenues have a significant impact on real GDP [6].

The results of an ARDL model confirm that the existence of a positive and significant long term impact of financial development on inclusive growth in Nigeria. At the same time, the model has revealed a negative relationship between public spending and inclusive growth [7].

In Morocco, according to an ARDL model, there is a negative impact of public expenditures on economic growth. These results can be explained, on the one hand, by the unproductive nature of public expenditures and, on the other hand, by a structure characterized by heaviness of debt spending, compensation and payroll [8].

According to Zulfiqar (2018) [9], the VAR models estimated to examine the impacts of different components of public expenditures and taxes on inclusive economic growth in Pakistan indicate that public expenditures, especially current expenditures, have the opposite impact on poverty reduction, income inequality and productive employment.

In Nigeria, according the Vector Auto Regressive (VAR) model estimated by Olubokun, Ayooluwade and Olumide (2016) [10] to examine the impact of government expenditure and inflation rate on economic growth from 1981 to 2013, the results indicate that economic growth is positively correlated with government expenditure. This implies that the increase in economic growth increases the demand for government 
expenditure, and therefore, the gross domestic product, which is likely to cause an appreciation of the value of government expenditure.

According to the paper of D. Raheem, O. Isah and A. Adedeji (2018) [11] who examined the relation between government expenditure on education and health and inclusive growth, the results obtained showed that both government expenditures are found to be significant for explaining growth in 18 Sub-Saharan Africa countries.

In Zimbabwe, Mazorodze (2018) [12] who applying the ARDL model for the period of 1979 - 2017, finds a significantly positive causal effect between public expenditure components (general consumption and investment expenditure) on long term and economic growth.

\section{Inclusive Growth in Morocco}

The Moroccan authorities have initiated in the last years a modernization process of the country, particularly through the acceleration of the structural transformation of the national economy, by focusing on industrialization and the promotion of exports, strengthening competitiveness and the encouragement of private investment. Thus, the Moroccan economy recorded a sustained growth rate. However, this economic growth has failed to reduce social inequalities and guarantee opportunities for all categories of the population. It is in this context that the debates currently in Morocco relate to the review of the development model and the strengthening of inclusive economic growth.

Inclusive economic growth is also the focus of many international institutions and organizations. However, it is important to firstly understand what is meant by the concept of "inclusive growth".

For the United Nations Development Program (UNDP) economic growth alone does not reduce poverty, improve equality or create jobs if it is not sustainable and does not benefit to everyone. Development can therefore only be inclusive if all categories of the population - whatever are their gender, ethnicity, age or social status - contribute to creating opportunities, share the benefits of development and participate in decision making.

In addition to the UNDP, the OECD [13] considers that « inclusive growth is based on the idea that economic growth is important but not sufficient to generate a sustainable increase in well-being, which implies an equitable sharing of the dividends of growth between individuals and social groups. Likewise, it is increasingly recognized that beyond income and wealth, well-being also depends on non-monetary factors, such as health and education».

In this context, investment in the human capital development can be an effective mechanism to enhance inclusive growth in Morocco. Even if the human capital development is a broad concept, this study considers investment in education and health its key indicator. In fact, education and health are among the United Nations Millennium Development Goals (MDGs) and Sustainable Development Goals recently.
In this regard, the study attempts to empirically examine the possibility of achieving inclusive growth through investment in the development of human capital (education and health).

\section{MODELING}

\section{A. Proposed Variables for Modeling the Impact of Public}

Expenditure on Inclusive Economic Growth in Morocco

The realization of this study took into account some variables suggested by economic theory, or tested in other countries, especially those in development.

The data used for the estimates are annual and covers the period from 1980 to 2018. They are obtained from the database of the World Bank, the Ministry of the Economy and Finance and the High Commission for Planning of Morocco.

The explanatory variables used in the modeling of the impact of public expenditures on inclusive economic growth in Morocco are as follows:

- GDP: Real gross domestic product;

- HCD: Expenditures on education and health (proxy for human capital development);

- INV: capital expenditures excluding capital expenditures on education and health;

- SUB: Government subsidies (proxy for ordinary expenditures);

- TR: Tax revenues;

- INF: The inflation rate.

\section{B. Correlation of the Variables Chosen with the GDP}

The analysis of the GDP correlation matrix with the selected macroeconomic variables (Table I) shows that:

- GDP increases with the rise of human capital development expenditures (HCD), capital expenditures (INV), government subsidies (SUB) and tax revenues (TR) with degrees of correlation of $99.1 \%, 96.3 \%$, $73.6 \%$ and $99.2 \%$ respectively;

- GDP falls with the rise in the rate of inflation with a degree of correlation of $-69.8 \%$.

TABLE I. CORRELATION MATRIX

\begin{tabular}{|l|l|l|l|l|l|l|}
\hline & $G D P$ & $H C D$ & $I N V$ & $S U B$ & $T R$ & $I N F$ \\
\hline GDP & 1 & & & & & \\
\hline HCD & $99.1 \%$ & $\mathbf{1}$ & & & & \\
\hline INV & $\mathbf{9 6 . 3 \%}$ & $\mathbf{9 5 . 4 \%}$ & $\mathbf{1}$ & & & \\
\hline SUB & $\mathbf{7 3 . 6 \%}$ & $\mathbf{7 4 . 4 \%}$ & $\mathbf{7 4 . 8 \%}$ & $\mathbf{1}$ & & \\
\hline TR & $\mathbf{9 9 . 2 \%}$ & $\mathbf{9 8 . 5 \%}$ & $\mathbf{9 6 . 4 \%}$ & $\mathbf{7 7 . 3 \%}$ & $\mathbf{1}$ & \\
\hline INF & $\mathbf{- 6 9 . 8 \%}$ & $\mathbf{- 6 6 . 9 \%}$ & $\mathbf{- 5 7 . 2 \%}$ & $\mathbf{- 4 6 . 0 \%}$ & $\mathbf{- 6 7 . 3 \%}$ & $\mathbf{1}$ \\
\hline \multicolumn{7}{|c|}{ Source: calculated by the authors / Eviews 9 }
\end{tabular}

\section{Analysis of the Stationarity of the Variables}

This section presents the results of the unit root tests to determine the stationarity and the order of integration of the 
variables. Most of the macroeconomic time series are nonstationary.

A variable is said to be non-stationary if the mean and / or the variance of the series are variable over time and the regression analysis of non-stationary variables poses the problem of spurious regression [14]. The time trend in the variables is the source of this problem. In this context, it is essential to check the stationarity of the series at first, before any econometric estimate.

In order to allow integration between the GDP and the variables to which it is linked, the methodology adopted for stationarity analysis of the variables consists in verifying the properties of the series using the Augmented Dickey fuller test (ADF test).

The stationarity test is shown in the Table II:

It appears from the results obtained from the stationarity test of the different series introduced into the developed model, as shown in Table II, that the GDP, HCD, INV, SUB and TR series are stationary at the first difference: I (1). The remaining variable: INF is stationary at the level: I (0).
The most suitable model for the data, namely stationary series integrated into different orders (I (0) and I (1)), is the ARDL (Autoregressive Distributed Lag) model.

\section{ARDL Model Specification}

The ARDL model (also known as: bounds testing approach to cointegration) was proposed by Pesaran and Smith (1998) [15] and improved by Narayan (2004) [16]. This model has also been tested in several empirical works.

The approach chosen in this study is the ARDL bounds test of Pesaran, since it is applicable to variables integrated into orders I (0) and I (1) (Pesaran and Shin, 2001) [17]. In addition, it does not present a bias even if the sample is very small (Mah, 2000). In addition, this approach examines both the long-term effects and the short-term dynamics of the variables.

The ARDL model for studying the long-term cointegration relationship between public expenditures and inclusive growth in this study is given as follows:

$$
\begin{aligned}
\Delta G D P_{t}= & \propto_{0}+\sum_{i=1}^{m} \propto_{1 i} \Delta G D P_{t-i}+\sum_{j=0}^{n} \propto_{2 i} \Delta H C D_{t-j}+\sum_{k=0}^{o} \propto_{3 i} \Delta I N V_{t-k}+\sum_{l=0}^{p} \propto_{4 i} \Delta S U B_{t-l}+\sum_{m=0}^{q} \propto_{5 i} \Delta T R_{t-m} \\
& +\sum_{n=0}^{r} \propto_{6 i} \Delta I N F_{t-n}+\propto_{7} G D P_{t-1}+\propto_{8} H C D_{t-1}+\propto_{9} I N V_{t-1}+\propto_{10} S U B_{t-1}+\propto_{11} T R_{t-1}+\propto_{12} I N F_{t-1}+\mu_{t}
\end{aligned}
$$

Where: GDP: Real gross domestic product, HCD: human capital development, INV: capital expenditures excluding capital expenditures on education and health, SUB: Government subsidies, TR: Tax revenues, INF: inflation rate and $\mu \mathrm{t}$ : the white noise error term.

The first part of the equation $\left(\alpha_{1}, \alpha_{2}, \alpha_{3}, \alpha_{4}\right.$ and $\left.\alpha_{5}\right)$ examines the short-term dynamic relationship, while the second part $\left(\alpha_{6}, \alpha_{7}, \alpha_{8}, \alpha_{9}, \alpha_{10}, \alpha_{11}\right.$ and $\left.\alpha_{12}\right)$ examines the long- term relationship term between public expenditures and inclusive growth.

The study took into account the Akaike information criterion (AIC) to determine the number of delays which is indicated by $\mathrm{m}, \mathrm{n}, \mathrm{o}, \mathrm{p}, \mathrm{q}$ and $\mathrm{r}$.

Thereafter, the study will test the cointegration relationship using the Peseran bound test.

\begin{tabular}{|c|c|c|c|c|c|c|c|c|}
\hline & \multicolumn{2}{|l|}{ Level } & \multirow{2}{*}{$\begin{array}{l}\text { Critical value } \\
-3.5\end{array}$} & \multicolumn{2}{|c|}{ 1st difference } & \multirow{2}{*}{$\begin{array}{l}\text { Critical value } \\
-3.5\end{array}$} & Conclusion & Order \\
\hline \multirow{2}{*}{ GDP } & t-Statistic & -0.9 & & t-Statistic & -12.2 & & \multirow{2}{*}{ Stationary } & \multirow{2}{*}{$\mathrm{I}(1)$} \\
\hline & P-value* & 0.9 & 0.05 & P-value & 0.00 & 0.05 & & \\
\hline \multirow{2}{*}{ HCD } & $\mathrm{t}$-Statistic & -1.7 & -3.5 & t-Statistic & -6.4 & -3.5 & \multirow{2}{*}{ Stationary } & \multirow{2}{*}{$\mathrm{I}(1)$} \\
\hline & P-value & 0.7 & 0.05 & P-value & 0.00 & 0.05 & & \\
\hline \multirow{2}{*}{ INV } & $\mathrm{t}$-Statistic & -1.2 & -3.5 & t-Statistic & -4.8 & -3.5 & \multirow{2}{*}{ Stationary } & \multirow{2}{*}{$\mathrm{I}(1)$} \\
\hline & P-value & 0.9 & 0.05 & $\mathrm{P}$-value & 0.002 & 0.05 & & \\
\hline \multirow{2}{*}{ SUB } & $\mathrm{t}$-Statistic & -2.3 & -3.5 & t-Statistic & -5.38 & -3.5 & \multirow{2}{*}{ Stationary } & \multirow{2}{*}{$\mathrm{I}(1)$} \\
\hline & $\mathrm{P}$-value & 0.4 & 0.05 & P-value & 0.00 & 0.05 & & \\
\hline \multirow{2}{*}{ TR } & $\mathrm{t}$-Statistic & -1.5 & -3.5 & t-Statistic & -5.7 & -3.5 & \multirow{2}{*}{ Stationary } & \multirow{2}{*}{$\mathrm{I}(1)$} \\
\hline & $\mathrm{P}$-value & 0.8 & 0.05 & $\mathrm{P}$-value & 0.00 & 0.05 & & \\
\hline \multirow{2}{*}{ INF } & $\mathrm{t}$-Statistic & -3.8 & -3.5 & t-Statistic & - & - & \multirow{2}{*}{ Stationary } & \multirow{2}{*}{$\mathrm{I}(0)$} \\
\hline & $\mathrm{P}$-value & 0.03 & 0.05 & P-value & - & - & & \\
\hline
\end{tabular}

TABLE II. RESULTS OF THE ADF TEST, 1980- 2018 


\section{E. Cointegration Test of the Series}

The analysis of cointegration between GDP and the explanatory variables is of great importance. This approach verifies the existence of a long-term dynamic in the GDP equation. The expected goal of this test is to examine the relationship between GDP and its determinants and to assess the rank of the cointegration space formed by these variables.

To test the existence of cointegration between the series, the econometric literature provides several tests or approaches including the bounds cointegration test of Pesaran and al. (2001) which was used as an analytical tool when there is a basket of variables with a different order of integration.

The test (Pesaran and Shin, 2001) [17] is expressed as follows: the hypothesis of the existence of a cointegration relation (H0) is accepted if the calculated Fisher is greater than the critical value of the upper bound I (1).

To apply the Pesaran cointegration test, two steps must be followed:

- Determine the optimal lag above all (Akaike Information Criterion (AIC));

- Use the Fisher test to test the cointegration between the series.

1) Optimal lag and estimation of the ARDL model: The study will use the Akaike Information Criterion (AIC) to select the optimal ARDL model (Fig. 1), one that offers statistically significant results with fewer parameters. Below the estimation results of the optimal ARDL model selected.

According to these results, the ARDL model (3, 3, 3, 0, 0, 4 ) is the most optimal among the 19 others presented, because it offers the smallest value of the Akaike information criterion (AIC).

Furthermore, with regard to the tests which help to diagnose the estimated ARDL model (Table III), which show the absence of autocorrelation of the errors and there is no heteroskedasticity (the errors are homoscedastic, that is to say that the variances of the errors are equal).

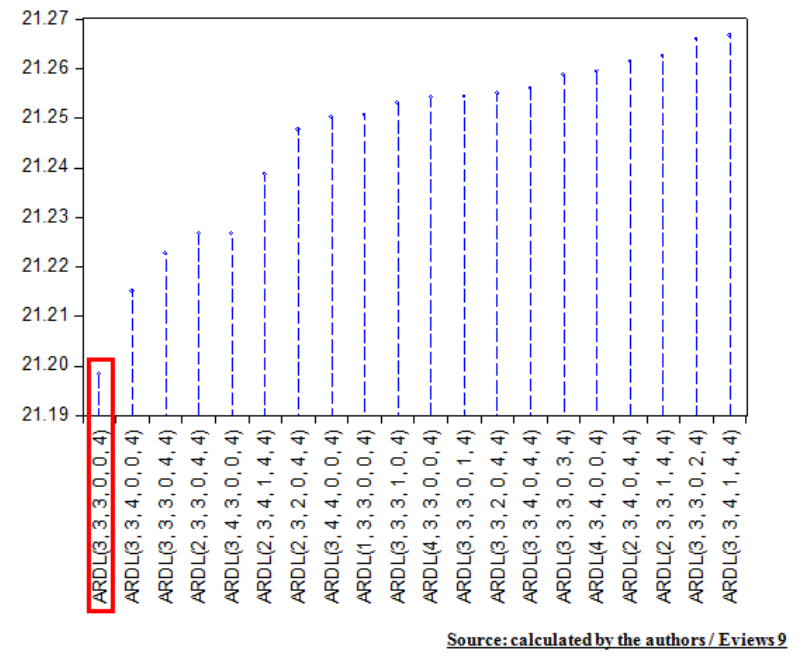

Fig. 1. Akaike Information Criterion (AIC).
TABLE III. Diagnostic TESTS

\begin{tabular}{|l|l|l|l|}
\hline $\begin{array}{l}\text { Hypothesis of the } \\
\text { test }\end{array}$ & Tests & $\begin{array}{l}\text { F-Statistic } \\
\text { values }\end{array}$ & Probability \\
\hline Serial correlation & Breuch-Godfrey & $\mathbf{1 . 5 4 2 7}$ & $\mathbf{0 . 2 4 8}$ \\
\hline \multirow{2}{*}{ Heteroskedasticity } & $\begin{array}{l}\text { Breuch-Pagan- } \\
\text { Godfrey }\end{array}$ & $\mathbf{1 . 3 4 3 3}$ & $\mathbf{0 . 2 7 9}$ \\
\cline { 2 - 4 } & ARCH-Test & $\mathbf{0 . 1 4 4 3}$ & $\mathbf{0 . 7 0 7}$ \\
\hline
\end{tabular}

Similarly, with regard to the CUSUM Test (Fig. 2) which gives an idea on the stability of the model, it confirms the stability of the model (the model is inside the two red lines).

2) The bounds cointegration test of pesaran: First, it should be noted that the bounds cointegration test of Pesaran (Table IV) requires an estimation of the ARDL model beforehand. The calculated test statistic, Fisher's F-value, will be compared to the critical values (which form bounds) as follows.

The results of the bounds cointegration test confirm the existence of a cointegration relationship between the variables, which gives the possibility of estimating the long-term effects of the explanatory variables on GDP.

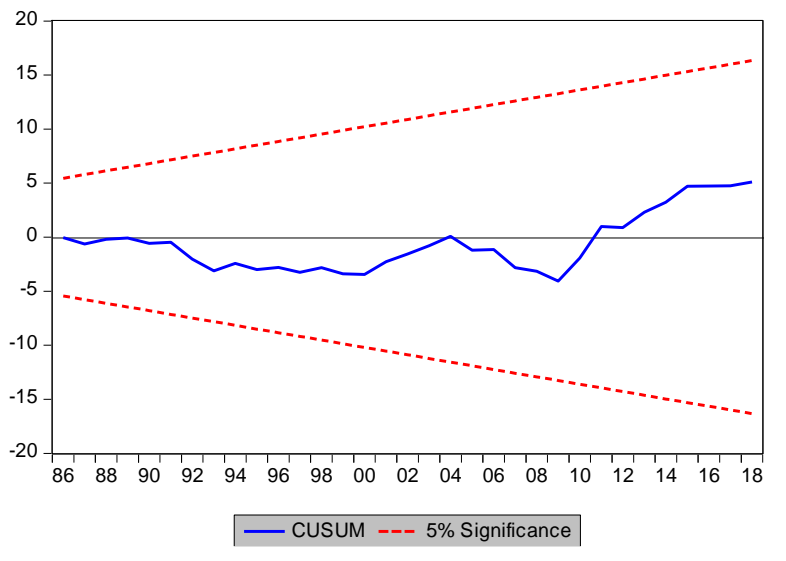

Source: calculated by the authors / Eviews 9

Fig. 2. CUSUM Test.

TABLE IV. Results of the Pesaran Test

\begin{tabular}{|c|c|c|c|}
\hline & \multicolumn{2}{|c|}{ Value } & Conclusion \\
\hline$F_{\text {calculated }}$ & \multicolumn{2}{|l|}{4.18} & \multirow{7}{*}{$\begin{array}{l}\text { In all the thresholds, } \\
F_{\text {calculated }}>\text { the critical } \\
\text { value of the upper } \\
\text { bound I }(1), \text { so } H_{0} \text { is } \\
\text { accepted. }\end{array}$} \\
\hline \multicolumn{3}{|c|}{ Critical values of bounds } & \\
\hline & $\mathrm{I}(0)^{*}$ & $\mathrm{I}(1)^{* *}$ & \\
\hline $10 \%$ & 2.08 & 3 & \\
\hline $5 \%$ & 2.39 & 3.38 & \\
\hline $2.50 \%$ & 2.7 & 3.73 & \\
\hline $1 \%$ & 3.06 & 4.15 & \\
\hline
\end{tabular}




\section{Results OF THE ESTIMATED ARDL MODEL}

\section{A. Short Term Coefficients (CT)}

According to the Table $\mathrm{V}$, the adjustment coefficient (CointEq (-1)) is negative and statistically significant, which guarantees an error correction mechanism with an adjustment speed towards equilibrium of $180 \%$ / year, and therefore the existence of a long-term equilibrium relationship between variables. This observation makes it possible to determine the necessary time to eliminate a given exogenous shock. Eliminating $99.9 \%$ of a GDP shock requires an average of three years.

The interpretation of these results is based on the analysis of the coefficients signs of the variables, having a significant probability compared to the $5 \%$ threshold, in the short term:

- Human Capital Development (HCD): Human capital development expenditures for the year (t) have a positive impact on economic growth in the same year. However, expenditures in years (t-1) and (t-2) have negative impacts on economic growth;

- Government subsidies (SUB) : have a negative impact on economic growth;

- Tax revenues (TR): have a positive impact on economic growth;

- Inflation (INF): inflation for the year (t) negatively affects growth in the same year. However, inflation lagged in ( $\mathrm{t}-1)$ and ( $\mathrm{t}-2)$ has a positive impact on economic growth, which is not in line with economic theory.

TABLE V. SHORT TERM COEFFICIENTS

\begin{tabular}{|l|l|l|l|l|}
\hline & Coefficient & Std.Error & t-Statistic & Prob. \\
\hline D(GDP(-1)) & -0.1 & 0.2 & -0.3 & 0.78 \\
\hline D(GDP(-2)) & -0.2 & 0.2 & -1.6 & 0.12 \\
\hline D(HCD) & 2.5 & 0.6 & 4.2 & 0.00 \\
\hline D(HCD(-1)) & -2.2 & 0.8 & -3.0 & 0.01 \\
\hline D(HCD(-2)) & -2.0 & 0.8 & -2.5 & 0.02 \\
\hline D(INV) & 1.1 & 0.8 & 1.3 & 0.21 \\
\hline D(INV(-1)) & -1.7 & 1.1 & -1.5 & 0.14 \\
\hline D(INV(-2)) & -1.4 & 0.8 & -1.8 & 0.08 \\
\hline D(SUB) & -0.8 & 0.3 & -2.8 & 0.01 \\
\hline D(TR) & 1.2 & 0.4 & 3.3 & 0.00 \\
\hline D(INF) & -444004.8 & 115796.8 & -3.8 & 0.00 \\
\hline D(INF) & 236851.9 & 95553.4 & 2.5 & 0.02 \\
\hline D(INF) & 434872.2 & 114127.6 & 3.8 & 0.00 \\
\hline D(INF) & 243021.3 & 112227.6 & 2.2 & 0.05 \\
\hline CointEq(-1) & -1.8 & 0.4 & -5.1 & 0.00 \\
\hline $\begin{array}{l}\text { CointEq = GDP - (5.78*HCD + 3.1*INV - 0.45*SUB + 0.68*TR } \\
-\mathbf{8 6 9 8 1 0 . 3 * I N F + 2 6 4 5 0 9 . 4 7 ) ~}\end{array}$ & & & \\
\hline
\end{tabular}

Source: calculated by the authors / Eviews 9

\section{B. Long Term Coefficients (LT)}

The interpretations of the long-term results (Table VI), following the same reasoning, are as follows:

- Human capital development (HCD): expenditures on human capital development have a positive impact on economic growth (if expenditures on HCD increases by 1 million of Moroccan Dirhams, real GDP will increase in the long term by 5.8 million of Moroccan Dirhams). This result is in line with the results of Balaev (2019) [19] and the positions of the economists of the endogenous growth theory, who state that public expenditures on human capital will stimulate economic growth. Likewise, this result corroborates the positions of international organizations, such as the UNDP and the OECD, which confirm that the development of human capital can be an effective mechanism for strengthening inclusive economic growth;

- Capital expenditures (INV): have a positive impact on economic growth (if capital expenditure increases by 1 million of Moroccan Dirhams, real GDP will increase in the long term by 3.1 million of Moroccan Dirhams);

- This result corroborates with results of Bahaddi \& Karim (2017) [20] and the recommendations of the economists of the Endogenous Growth Theory who do not consider public expenditures as a whole but they make a distinction between its different categories and encourage capital expenditures, particularly in infrastructure;

- Government subsidies (SUB):These expenditures (proxy for ordinary expenditures) has a negative impact on economic growth (if government subsidies increase by 1 million of Moroccan Dirhams, real GDP will decrease by 0.5 million of Moroccan Dirhams in the long term), which confirms the remarks of the Keynesian Theory detractors, who criticize the excessive use of public expenditure, especially government consumption expenditure, to stimulate economic growth;

- Tax revenues (TR): have a positive impact on economic growth (if tax revenue increases by 1 million of Moroccan Dirhams, real GDP will increase by 0.7 million of Moroccan Dirhams in the long term). However, the public authorities must monitor the tax burden on taxpayers.

- Inflation (INF): Inflation has a negative impact on economic growth (if inflation increases by $1 \%$, real GDP will decrease in the long term by almost 8.7 million of Moroccan Dirhams). Inflation in Morocco remains in a controlled level, around $2 \%$, in recent years following the rigorous monetary policy followed by the Central Bank. However, accelerating of the inflationary pressures can dampen economic growth. 
TABLE VI. LONG TERM COEFFICIENTS

\begin{tabular}{|l|l|l|l|l|}
\hline & Coefficient & Std. Error & t-Statistic & Prob. \\
\hline HCD & 5.8 & 0.5 & 11.6 & 0.00 \\
\hline INV & 3.1 & 0.3 & 10.4 & 0.00 \\
\hline SUB & -0.5 & 0.1 & -4.2 & 0.00 \\
\hline TR & 0.7 & 0.2 & 4.5 & 0.00 \\
\hline INF & -869810.3 & 58380.0 & -14.9 & 0.00 \\
\hline C & 264509.5 & 5836.3 & 45.3 & 0.00 \\
\hline
\end{tabular}

\section{CONCLUSION}

This study empirically analysed the impacts of human capital development and capital expenditures on economic growth. The results of the estimates through the ARDL model show that if human capital development expenditures (education and health expenditures) increase, this will strengthen inclusive growth. The model also shows that capital expenditures have positive effects on economic growth while operating expenditures have a negative impact.

To improve economic growth, Morocco should step up its public investment efforts and rationalize its operating expenditures. Increasing the productivity level would rise the creation of job vacancies, as well as tax revenues. However, increasing economic growth is not an end in itself, but a mean to achieve inclusive growth, to reduce social inequalities and guarantee opportunities for all categories of the population.

Overall, the econometric results attest to the positive impact that the human capital development can have on inclusive growth in Morocco. As a result, promoting inclusive growth should involve effective policymaking of human capital development and other development interventions. New research should be carried out focusing on the disaggregation of the other components of public expenditure through which fiscal policies influence inclusive growth.

At the end, some limits of this study may constitute avenues of research for future studies. The variables used are purely quantitative, therefore it would be advisable in future research, if data over a sufficiently long period are available, to use variables which integrate the quality of education and health services.

\section{REFERENCES}

[1] John Maynard Keynes (1936). General Theory of Employment, Interest and Money.

[2] Robert J. Barro \& Xavier SALA-I-MARTIN (2004). Economic Growth. Cambridge: the MIT Press.
[3] Bongumusa Prince Makhoba, Irrshad Kaseeram et Lorraine Greyling (2019). Assessing the Impact of Fiscal Policy on Economic Growth in South Africa. African Journal of Business and Economic Research (AJBER).

[4] Kirandeep Kaur (2018). Composition of Public Expenditure and Economic Growth in India: A Time Series Analysis. International Journal of Social Science.

[5] Anouar Ghazi (2018). Effets macroéconomiques des chocs de la politique budgétaire au Maroc: Une analyse en VAR structurel linéaire. International Journal of Innovation and Applied Studies .

[6] MESSAILI, Moussa and KAID TLILANE, Nouara (2018). An assessment of the contribution of health to economic growth in Algeria. Munich Personal RePEc Archive.

[7] Adediran Oluwasogo S, Oduntan, Emmanuel and Matthew Oluwatoyin (2017). Financial development and inclusive growth in Nigeria: a multivariate approach. Journal of Internet Banking and Commerce.

[8] Jaouad OBAD and Youssef JAMAL (2016). L'impact des dépenses publiques sur la croissance économique au Maroc : Application de l'approche ARDL. International Journal of Innovation and Applied Studies.

[9] Kalsoom Zulfiqar (2018). Fiscal Policy for Inclusive Growth: a Case Study of Pakistan. Pakistan Economic and Social Review Volume 56, No. 1 (Summer 2018), pp. 21-46.

[10] Sanmi Olubokun, Ebiwonjumi Ayooluwade and Fawehinmi Festus Olumide (2016). Government Expenditure, Inflation Rate and Economic Growth in Nigeria (1981-2013): A Vector Autoregressive Approach. Romanian Journal of Fiscal Policy Volume 7, Issue 1(12), January-June 2016, Pages 1-12.

[11] Ibrahim D. Raheem, Kazeem O. Isah and Abdulfatai A. Adedeji (2018). Inclusive growth, human capital development and natural resource rent in SSA. Econ Change Restruct (2018) 51:29-48.

[12] Brian Tavonga Mazorodze (2018). Government Expenditure and Economic Growth in Zimbabwe. African Journal of Business and Economic Research (AJBER)Vol. 13, (Issue 2), August 2018 pp 183 202.

[13] The Organisation for Economic Co-operation and Development (OECD), (2014). Rapport sur le cadre de l'OCDE pour une croissance inclusive.

[14] Engle, R.F. \& Granger C.W.J. (1987). Co-integration and error correction: representation, estimation and testing. Econometrica.

[15] Hashem Pesaran and Ron P.Smith (1998). Structural analysis of cointegrating VARs. Journal of economic surveys.

[16] Narayan, P.K. (2004). Reformulating Critical Values for the Bounds FStatistics Approach to Cointegration : An Application to the Tourism Demand Model for Fiji. Department of Economics, Discussion Papers, No.02/04, Monash University, Victoria 3800, Australia.

[17] Hashem Pesaran, Yongcheol Shin and Richard J. Smith (2001). Bounds Testing Approaches to the Analysis of Level Relationships. Journal of Applied Econometrics.

[18] Blanchard, O. \& Perotti, R. (2002). An Empirical Characterization of the Dynamic Effects of Changes in Government Spending and Taxes on Output. The Quarterly Journal of Economics, 117, 1329-68.

[19] Alexey Balaev (2019). The Structure of Public Spending and Economic Growth in Russia. Russian Journal of Economics 5 (2019) 154-176.

[20] Tlaytmaste Bahaddi \& Mohamed Karim (2017). «Impact of Public Expenditure on the Growth in Morocco: Role of Governance». International Journal of Economics and Finance. 